\title{
ASSESSMENT OF ANTIMICROBIALS USAGE IN COMMERCIAL FARROW-TO-FINISH PIG HOLDINGS IN VOJVODINA REGION (SERBIA)
}

\author{
Jasna Prodanov-Radulovići ${ }^{*}$, Andrea Lauková ${ }^{2}$ Lubomíra Grešáková2, \\ Ivan Pušić ${ }^{1}$, Živoslav Grgić ${ }^{1}$, Jelena Petrović ${ }^{1}$, Igor Stojanov ${ }^{1}$ \\ ${ }^{1}$ Scientific Veterinary Institute "Novi Sad", Novi Sad, Republic of Serbia \\ ${ }^{2}$ Institute of Animal Physiology, Centre of Biosciences of \\ the Slovak Academy of Sciences, Košice, Slovakia
}

\section{Abstract}

Antimicrobial use is considered to be the highest in pig production as compared with other animal husbandry sectors. In Serbia, antimicrobials have wide application at pig farms as therapeutic but also as a prophylactic treatment. The aim of the research study was the assessment of antimicrobial usage in different stages of pig production in commercial farrow-to-finish pig holdings located in Vojvodina Province (Serbia). A total of eleven pig holdings located in the Vojvodina Province were included in this research. All investigated herds were single site farrowto-finish production systems with minimum of 300 sows in the site. The data on prophylactic and therapeutic measures on the investigated farms were obtained from official farm treatment records provided by the veterinarians and/or farmers. The antimicrobials usage on pig farms was recorded by product, administration route and animal production category. The analysis of recorded data revealed that different types of antimicrobials from almost all groups were applied. Breeding pigs (sows, boars) received less treatment as compared to growing categories. As regards the types of antimicrobials, frequent use of cephalosporins and polymyxins in growing piglets was detected. The group treatments were mostly preventive and the administration of an antimicrobial often lacked a precise previous diagnosis. Administration of high amounts of macrolides and pleuromutilins (tiamulin), quite often in combination with tetracyclines in the fattening stage was noticed. In conclusion, significant level of prophylactic antimicrobial treatments in farrow-tofinish pig farms in Serbia is evident. The present study was initiated as a first step for comparing antimicrobial usage on herd level using available data.

Key words: antimicrobials, pig farms, Vojvodina Province

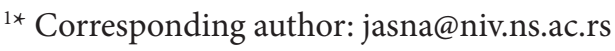




\title{
PRIMENA ANTIMIKROBNIH PREPARATA NA KOMERCIJALNIM FARMAMA SVINJA OD PRAŠENJA DO TOVA U REGIONU VOJVODINE (SRBIJA)
}

\author{
Jasna Prodanov-Radulović ${ }^{*}$, Andrea Lauková ${ }^{2}$, Lubomíra Grešáková2, \\ Ivan Pušić ${ }^{1}$, Živoslav Grgić ${ }^{1}$, Jelena Petrović ${ }^{1}$, Igor Stojanov ${ }^{1}$ \\ ${ }^{1}$ Naučni institut za veterinarstvo "Novi Sad”, Novi Sad, Republika Srbija \\ ${ }^{2}$ Institut za fiziologiju životinja, Centar za biološke nauke, \\ Slovačka Akademija nauka, Košice, Slovačka
}

\section{Kratak sadržaj}

Smatra se da je svinjarska proizvodnja sektor stočarstva sa najvećom primenom antimikrobnih preparata. Na farmama svinja u Srbiji antimikrobni lekovi imaju široku primenu, u terapiji ali i u okviru mera profilakse. Cilj istraživanja je bio analiza primene antimikrobnih preparata $u$ različitim fazama proizvodnje na komercijalnim farmama svinja organizovanih od prašenja do tova, u regionu Vojvodine (Srbija). Istraživanjem je obuhvaćeno ukupno jedanaest farmi svinja u Vojvodini. Svi obuhvaćeni komercijalni zapati predstavljaju proizvodne sisteme od prašenja do tova sa najmanje 300 krmača. Analizom su obuhvaćeni podaci o profilaktičkim i terapijskim merama na farmama iz zvaničnih farmskih evidencija dobijenih od veterinara i/ili farmera. Analizirana je primena antimikrobnih preparata prema proizvodu, načinu aplikacije kao i proizvodnoj kategoriji. Utvrđeno je da se različiti antimikrobni preparati primenjuju u svim fazama proizvodnje. Rezultati ukazuju da su priplodne jedinke (krmače, nerastovi) podvrgnute značajno manjem broju terapijskih tretmana u poređenju sa mladim jedinkama u porastu. Sa aspekta analize različitih grupa antimikrobnih lekova, utvrđena je česta primena cefalosporina i polimiksina u kategoriji jedinki u porastu. Grupni tretmani su uglavnom preventivni, pri čemu često izostaje prethodna dijagnostika. U fazi tova učestala je primena makrolida i pleuromutilina, često u kombinaciji sa tetraciklininima. U zaključku, utvrđena je značajna profilaktička primena antimikrobnih preparata na farmama svinja od prašenja do tova u Srbiji. Istraživanje predstavlja prvi korak u cilju sagledavanja potrošnje antimikrobnih preparata na nivou zapata svinja iz postojećih dostupnih podataka.

Ključne reči: antimikrobni preparati, farme svinja, region Vojvodine 


\section{INTRODUCTION}

In the past, antimicrobial usage (AMU) in animal husbandry was frequently aimed at therapeutic but also at preventive treatment (McEwen and Fedorka-Cray, 2002). However, since recently, AMU in livestock systems has been associated with the problem of antimicrobial resistance (AMR) (Raasch et al., 2020). The ban of AMU as growth promoters was applied by the European Union (EU) in 2006 (Diana et al., 2019; Raasch et al., 2018). Pursuant to legal directives, continuous monitoring of AMR is performed in EU member countries (Echtermann et al., 2019). Today, the problem of AMR is considered one of the major global threats for the future as it undermines the possibility to effectively treat bacterial diseases in both humans and animals. Resistant bacteria that emerge among food producing animals can spread to humans, along the food production chain and in the environment (Silbergeld et al., 2008; Baquero, 2011), so reduction of AMU is therefore essential (Raasch et al., 2018). However, prophylactic AMU is still present in many countries in order to sustain animal health and welfare (Sjölund et al., 2016; Diana et al., 2019).

Pig production is considered to be amongst the animal husbandry sectors with the highest AMU (Callens et al., 2012; Collineau et al., 2017). Prophylactic AMU aimed at preventing infections is a common practice on pig farms, especially during stressful periods for some categories (Prodanov-Radulović et al., 2014a; Prodanov-Radulović et al., 2015a; Corinne et al., 2016). Antimicrobials are incorporated in feed or water for disease prophylaxis, and they are typically removed at the finishing stages of production to avoid residues in tissues (McEwen and Fedorka-Cray, 2002; Došen et al., 2014; Prodanov-Radulović et al., 2014b). Although limited and responsible AMU is desirable, recent studies indicated that therapeutic but also prophylactic AMU in pig population has increased in Serbia (Prodanov-Radulović et al., 2014b; Prodanov-Radulović et al., 2020). The commercial farrow-to-finish pig production is situated mostly in the north of the country (Vojvodina Region) (Prodanov-Radulović et al., 2015b; Prodanov-Radulović et al., 2017a). In present conditions, it is considered that AMU in Serbia is closely interrelated with the structure of livestock production, high infectious pressure and existing biosecurity measures (Došen et al., 2014; Prodanov-Radulović et al., 2017b; Prodanov-Radulović et al., 2018). As compared to a multi-site production systems, farrow-to finish swine farms offer more supporting environment for interactions between pathogens, environment and management (Savić et al., 2015; Prodanov-Radulović et al., 2020). The aim of the research was the assessment of AMU in different stages of pig production in commercial farrow-to-finish pig holdings located in Vojvodina Province (Serbia). 


\section{MATERIAL AND METHODS}

Eleven pig holdings located in the Vojvodina Province were included into this research. To meet the criteria to be included in the study, the herds had to be single site farrow-to-finish production systems with minimum 300 sows in the site. All selected pig farms had their own veterinary service or at least one full-time veterinarian. Basic production characteristics were common to the majority of selected farrow-to-finish farms, i.e., the piglets were weaned at the age of 28-35 days, and then transferred to a weaning, and later to growing and fattening units. Finishing pigs were slaughtered at a weight of approximately $110 \mathrm{~kg}$ or when reaching age of 25 weeks. All selected farms were involved in health surveillance program in the previous period. The herd health history of bacterial and/or viral infections among different categories was well-documented (Prodanov-Radulović et al., 2014a; Prodanov-Radulović et al., 2015a; Prodanov-Radulović et al., 2015b; Prodanov-Radulović et al., 2017b).

Herd visits took place between January 1 and November 30, 2019. During the herd visits, detailed data about AMU in all categories were collected. All herds were examined by the same investigator according to a standardized protocol. The data on prophylactic and therapeutic measures on the investigated farms were obtained from official farm treatment records provided by the veterinarians and/or farmers. The following details were ascertained from farm records: number and category of pigs in the unit, production details, disease status and current veterinary health plan. The veterinarians were required to allocate the AMU to five different production groups in farrow-to-finish production: sows, boars, suckling and weaned piglets, fatteners. Based on the available records, the AMU on pig farms was recorded by product, administration route and production category.

\section{RESULTS}

The data on the frequency of certain AMU according to the production categories: sows, boars, suckling and weaned piglets, fattening pigs were collected and analyzed. Prophylactic AMU in sows was most commonly based on a combination of lincomycin hydrochloride and spectinomycin sulphate (12.06\%) but also combination of tiamulin hydrogen fumarate and oxytetracyclin (10.34\%) (Figure 1). According to farm production data, appropriate powdered forms of these antimicrobials were mostly used in the period of late pregnancy, i.e., 7 to 14 days before farrowing. As regards the therapeutic treatment of sows, preparations of procaine benzyl penicillin and dihydrostreptomycin sulphate (15.51\%) administered parenterally were used. Most fre- 
quently, they were administered in the first 3 days after parturition in order to prevent puerperal infections and possible health complications. Also, the sows were frequently treated with tiamulin hydrogen fumarate and oxytetracyclinebased preparations in the form of dehydrate (13.79\%).

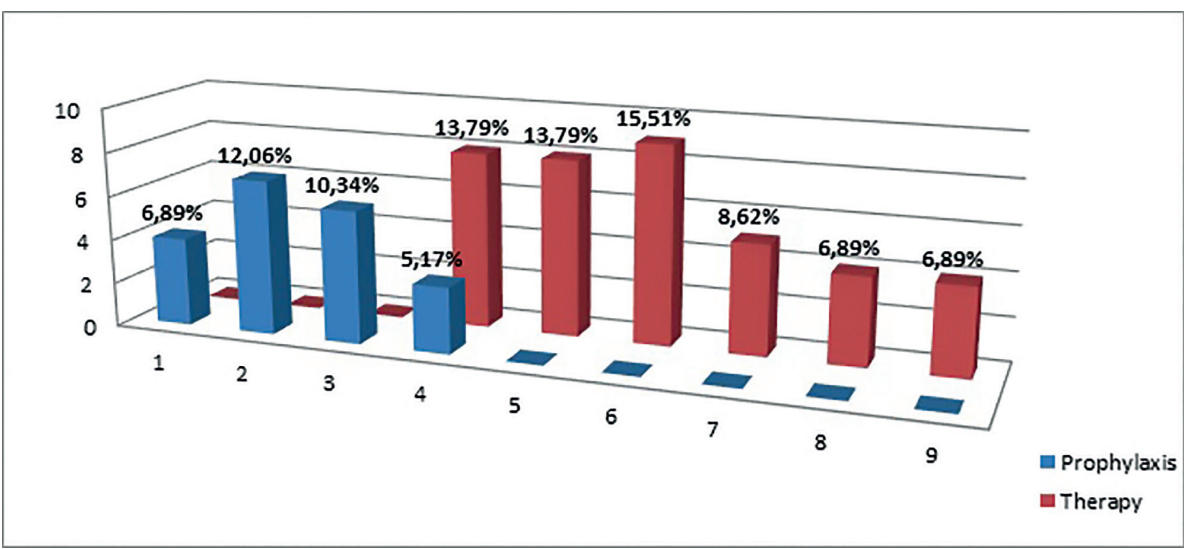

Figure 1. The antimicrobials usage in sow's category in eleven farrow-to-finish pig holdings. Antibiotics: lincomycin hydrochloride sulphate (1), Lincomycin hydrochloride + Spectinomycin sulphate (2), Tiamulin hydrogen fumarate + Doxycycline hydrochloride (3), Tiamulin hydrogen fumarate (4), Oxytetracycline dihydrate (5), Procaine benzylpenicillin + Dihydrostreptomycin sulphate (6), Streptomycin sulphate (7), Florfenicol (8) and Enrofloxacin (9).

In all examined pig farms, there was no standard antimicrobial prophylactic protocol for breeding boars. The therapeutic treatment of boars was mainly applied in accordance with established clinical picture and relevant disease diagnosis. The combinations of tiamulin hydrogen fumarate and doxycycline hydrochloride (22.22\%), as well as tiamulin hydrogen fumarate as the sole substance were most commonly administered in the therapy. The parenteral use of oxytetracycline dihydrate, fluorophenicol and enrofloxacin has also been reported (Figure 2). 


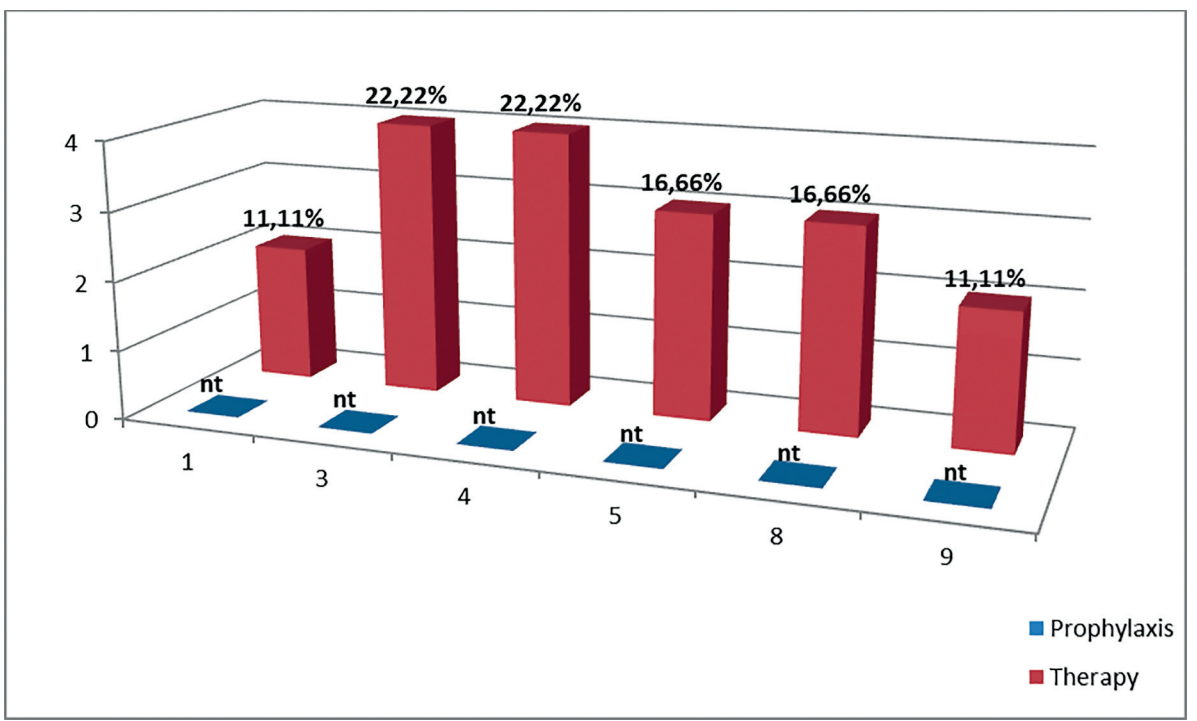

Figure 2. The antimicrobials usage in breeding boars in eleven farrow-to-finish pig holdings. Antibiotics: Lincomycin hydrochloride sulphate (1), Tiamulin hydrogen fumarate + Doxycycline hydrochloride (3), Tiamulin hydrogen fumarate (4), Oxytetra cycline dehydrate (5), Florfenicol (8), Enrofloxacin (9) and nt - no treatment record.

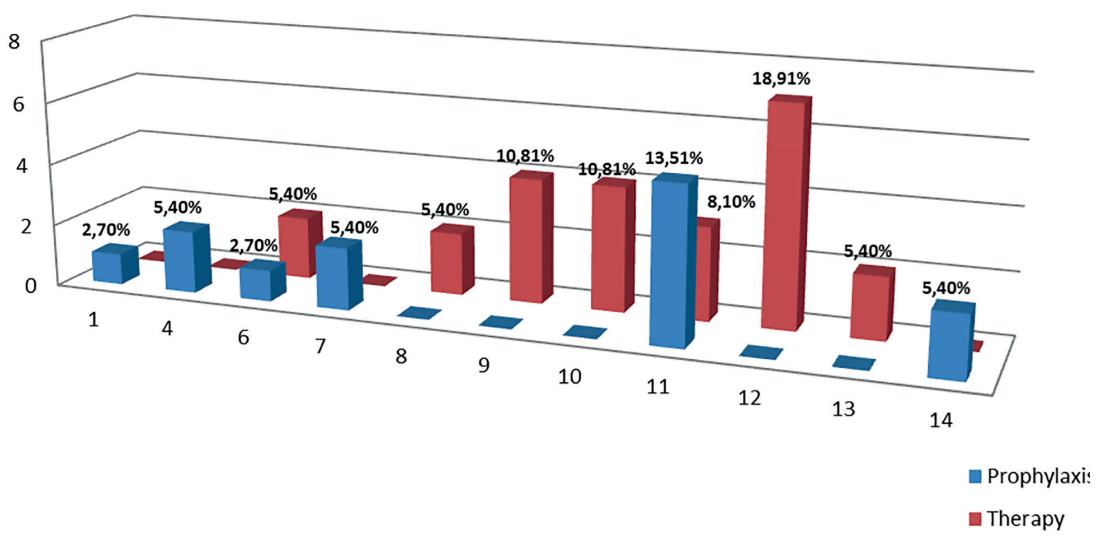

Figure 3. The antimicrobials usage in suckling piglets in eleven farrow-to-finish pig holdings. Antibiotics: Lincomycin hydrochloride sulphate (1), Tiamulin hydrogen fumarate (4), Procaine benzyl penicillin + Dihydrostreptomycin sulphate (6), Streptomycin sulphate (7), Florfenicol (8), Enrofloxacin (9), Amoxicillin trichydrate (10), Colistin sulphate (11), Cefquinome sulphate (12), Gentamicin sulphate (13) and Sulfadimidine + oxytetracycline hydrochloride + neomycin sulphate (14). 
In sucklings, prophylactic treatment mostly included application of watersoluble colistin sulfate (13.51\%). However, prophylactic usage of commercial preparations containing at the same time more than one active substances was established. Parenteral application involved the administration of a number of different AMs, most frequently cefquin sulphate-based preparations (Figure 3).

In the category of weaned piglets, in the period just before or after the piglets are weaned, per os administration of amoxicillin trihydrate was frequently detected (14.89\%). In the therapeutic treatment of weaned piglets, the combination of trimethoprim-sulfametoxasol was dominant (18.63\%) followed by florfenicol (14.89\%) and enrofloxacin (Figure 4).

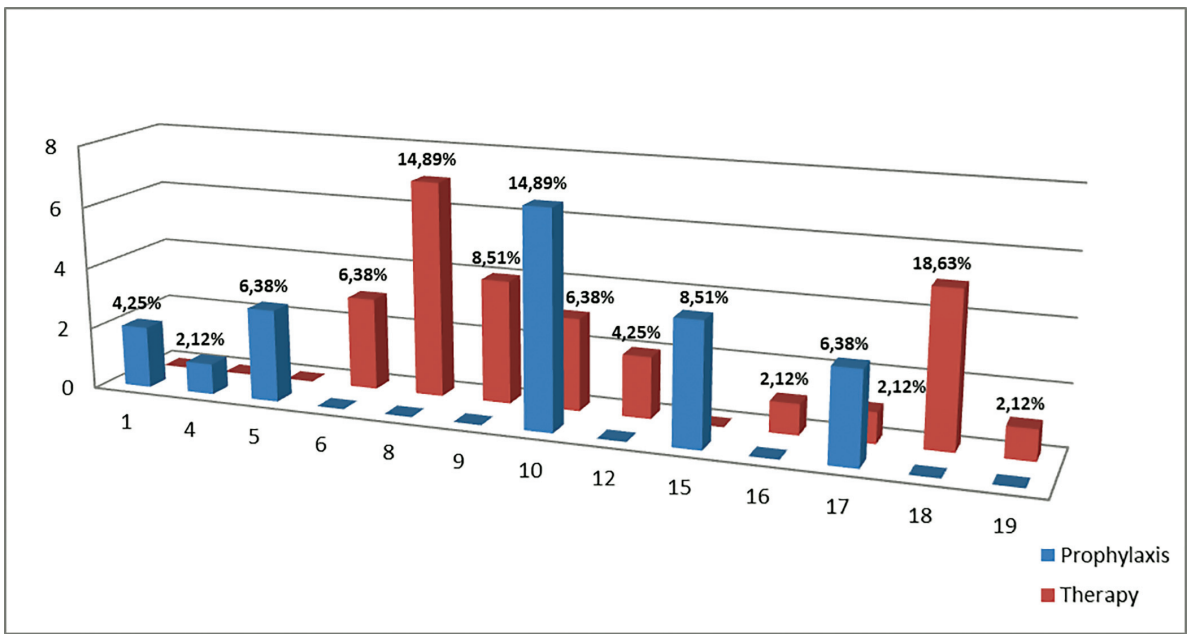

Figure 4. The antimicrobials usage in weaned piglets in eleven farrow-to-finish pig holdings. Antibiotics: Lincomycin hydrochloride sulphate (1), Tiamulin hydrogen fumarate (4), Oxytetracycline dehydrate (5), Procaine benzyl penicillin + Dihydrostreptomycin sulphate (6), Florfenicol (8), Enrofloxacin (9), Amoxicillin trichydrate (10), Cefquinome sulphate (12), Tulathromycin (15), Doxycyclin hiklate (16), Neomycin sulphate (17), Trimethoprim + Sulphametoxazole (18) and Ceftiofur hydrochloride (19).

In fattening pigs, tiamuline hydrogen fumarate-based preparations, alone or in combination with doxycycline hydrochloride, as well as the administration of oxytetracycline in the form of dihydrate were dominant in the prophylaxis. In the therapy of fatteners, oxytetracycline in the form of dihydrate and florfenicol were most frequently the antimicrobials of the first choice (Figure 5). 


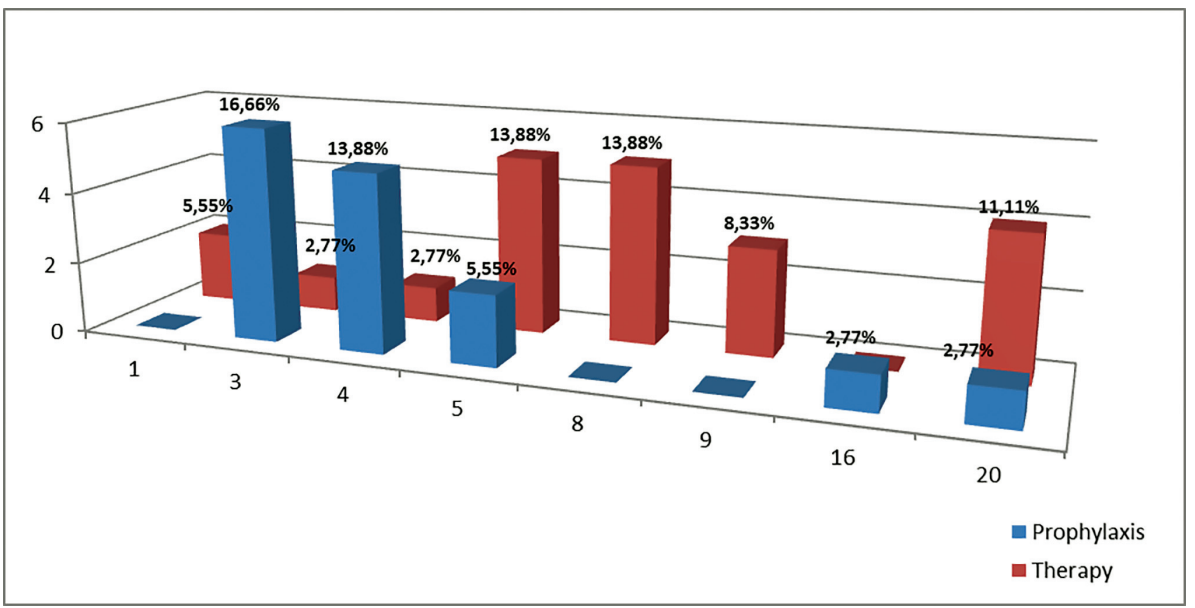

Figure 5. The antimicrobials usage in fatteners in eleven farrow-to-finish pig holdings. Antibiotics: Lincomycin hydrochloride sulphate (1), Tiamulin hydrogen fumarate + Doxycycline hydrochloride (3), Tiamulin hydrogen fumarate (4), Oxytetracycline dehydrate (5), Florfenicol (8), Enrofloxacin (9), Doxycyclin hiklate (16) and Tylozin tartarate (20).

\section{DISCUSSION}

The analysis of recorded data in farrow-to-finish pig holdings revealed that AMU was common practice during all production phases, i.e., different types of antimicrobials from almost all groups were applied. The selected holdings are situated in Vojvodina Province, where majority of commercial pig production takes place, indicating that the obtained results gave a good insight into AMU in pig production in Serbia. Breeding pigs (sows, boars) received less treatment as compared to growing categories. According to the farmers, the aim of prophylactic treatment of sows was preventing the occurrence of disorders in late pregnancy and potential gastrointestinal infections in newborns. During other phases of sow production, AMU depended on the overall health status and/or current health issues, for instance respiratory and /or reproductive infections, lameness etc. In all examined herds, no preventive treatments of boars were reported, and, this was also the category with the lowest overall AMU. Contrary to that, suckling and weaned pigs received the most of the treatments. In newborns and at weaning, antimicrobials were commonly administered orally, as prophylactic group-treatments aimed at preventing diarrhea.

Group-level treatments are the common way of AMU in pig production. The majority of these treatments are prophylactic, administered to groups of pigs at critical time-points in production such as weaning (Callens et al., 2012; 
Corinne et al., 2016). Based on the experience, most farmers recognize the critical time points, when their pigs get ill (Raasch et al., 2018). Indeed, on all evaluated pig farms, the weaning period was indicated as the period when significant health problems were notified (diarrhea caused by Escherichia coli, infections with Streptococcus suis, respiratory infections). The process of weaning introduces a number of stress factors that may influence the immune function and intestinal microflora of weaned pigs. These disturbances might challenge the risk of different enteric disorders (Sjolund et al., 2016). According to Postma et al. (2016) a higher weaning age was associated with a lower necessity for AM therapy.

The pig industry uses more antimicrobials than any other livestock sector, especially during the weaning period, when pigs face several challenges and stressors including changes in the diet, separation from the sow and re-mixing. The practice of prophylactic AMU to a group is a way of reducing the risk of disease in weaned pigs. However, excessive use or misuse of broad-spectrum AM poses a serious threat for public health (Diana et al., 2019). Group treatment represented the most common way to treat growing pigs in the herds at strategic time points when pigs were prone most likely to contract disease (Sjolund et al., 2016). In our study, commercial in-feed medication was recorded in all participating farms. Indeed, in Vojvodina Region, feed mills frequently have the manufacturing authorization to produce commercial in-feed medication (Došen et al., 2014). This method of AMU in Serbia is still frequent, despite being almost obsolete in some EU countries (Echtermann et al., 2019). In-feed medication is ideal for prophylactic use, but once pigs get clinically ill, in-feed medication can be ineffective. A properly functioning water supply is an ideal route for mass medication of pigs (Došen et al., 2014).

As regards the antimicrobials considered especially critical to human medicine (Callens et al., 2012; Sjolund et al., 2016), we established a relatively frequent use of cephalosporins in growing pigs. In most EU countries, the use of cephalosporins in pigs has been highly regulated or even banned (Echtermann et al., 2019). According to our research results, frequent application of polymyxins (colistin) is particularly worrying because reduction of its use is highly recommended. Moreover, guidelines explicitly state that colistin is a last-resort drug in human medicine, which should not be used as a substitute for good management practices (Sjolund et al., 2016). Frequent use of polymixins indicates that diarrhea still continues to be a major challenge in pig production (Prodanov-Radulović et al., 2015b).

The group-treatments in fattening stage were mostly of preventive nature and often lacked a precise previous diagnosis. High amounts of macrolides and 
pleuromutilins, quite often in combination with tetracyclines were observed in this age group. Farmers reported that fattening pigs were commonly treated for respiratory disorders. However, therapeutic treatments of individual pigs were not always recorded, and it was difficult to obtain reliable retrospective information on the therapeutic AMU in fatteners. According to the results of previous study (Prodanov-Radulović et al., 2014b; Prodanov-Radulović et al., 2020), swine dysentery and respiratory infections were most frequently diagnosed during the fattening stage.

It is suggested that improved biosecurity in pig farming could lead to a better health status and thus to a reduced AMU (Laanen et al., 2013). The correct management of diseased animals results in a lower risk of within-herd spread of infection, which in turn leads to reduced infection pressure and a mitigation of AMU (Callens et al., 2012; Collineau et al., 2017). Having in mind the obtained results, and in order to successfully reduce AMU, on-farm action is needed. It is obvious that current farrow-to-finish production systems provide more opportunities for multiple interactions between pathogens, as compared to multi-site production systems (Savic et al., 2015; Prodanov-Radulovic et al., 2020). There are several examples of disease outbreaks due to insufficient implementation of external biosecurity measures in pig holdings in Serbia, such as Pseudoreabies (Prodanov-Radulović et al.,2015b) and porcine epidemic diarrhea (Prodanov-Radulović et al., 2017b). The improvement of biosecurity measures is an important approach to prevent the entry and spread of pathogens in a herd and thus may reduce the necessity of AMU (Laanen et al., 2013; Raasch et al., 2018). Therefore, reduction and promotion of a more prudent AMU in pig production is important (Echtermann et al., 2019; Raasch et al., 2020).

Commercial pig production in Serbia implies classical, old-type farrowto-finish farm structure (Došen et al., 2014; Prodanov-Radulović et al., 2020) and there is no central AMU database that could be used to set benchmarks for antimicrobial consumption. Having in mind the results of our previous epidemiological survey (Prodanov-Radulović et al., 2018), a biosecurity guidance for pig holdings should be created with the aim of upgrading biosecurity measures and therefore improving pig health resulting in the decrease of AMU.

\section{CONCLUSION}

Significant level of AMU in farrow-to-finish pig farms in Serbia in prophylactic treatments is evident. Development of a national program for monitoring of AMU is highly required. Moreover, initiation of control and regula- 
tion measures for prescription and distribution of antimicrobials coupled with farmers' education is of crucial importance.

\section{Acknowledgements}

This article is based upon work from Scientific and Technological cooperation between the Republic of Serbia and the Slovak Republic, bilateral project number: 337-00-107/2019-09/14 and SK-SRB-18-0001, project title: Bacteriocins, a safe way to inhibit antibiotic resistant bacteria from pigs for healthy farming, supported by the Ministry of Education, Science and Technological Development of the Republic of Serbia, and by APVV agency of Slovak Republic.

\section{Author's contributions:}

PRJ and PI were involved in the data collection on pig farms. PJ, GŽ, LA contributed with results analysis and the way of results presenting. LA and LG revised the manuscript and together with SI and PRJ prepared the final draft of the manuscript. All authors read and approved the final manuscript.

\section{Competing of interests}

The Authors have no conflict of interest to declare.

\section{REFERENCES}

1. Baquero F. 2011. The 2010 Garrod Lecture: The dimensions of evolution in antibiotic resistance: ex unibus plurum et ex pluribus unum. Journal of Antimicrobial Chemotherapy, 66, 8, 1659-1672. doi:10.1093/jac/dkr214.

2. Callens B., Persoons D., Maes D, Laanen M., Postma M., Boyen F., Haesebrouck F., Butaye P., Catry B., Dewulf J. 2012. Prophylactic and metaphylactic antimicrobial use in Belgian fattening pig herds. Preventive Veterinary Medicine, 106, 1, 53-62. doi:10.1016/j.prevetmed.2012.03.001.

3. Collineau L., Rojo-Gimeno C., Léger A., Backhans A., Loesken S., Nielsen E.O., Postma M., Emanuelson U., Beilage E.G., Sjölund M., Wauters E., Stärk K.D.C., Dewulf J., Belloc C., Krebs S. 2017. Herd-specific interventions to reduce antimicrobial usage in pig production without jeopardizing technical and economic performance. Preventive Veterinary Medicine, 144,167-178. doi:10.1016/j.prevetmed.2017.05.023. 
4. Corinne A., Schüpbach-Regula G., Hirsiger P., Malik J., Scheer P., Sidler X., Spring P., Peter-Egli J., Harisberger M. 2016. Risk factors for oral antimicrobial consumption in Swiss fattening pig farms - a case-control study. Porcine Health Management, 2, 5. doi:10.1186/s40813-016-0024-3.

5. Diana A., Boyle L.A., Leonard, F.C., Carroll C., Sheehan E., Murphy D., Manzanilla E.G. 2019. Removing prophylactic antibiotics from pig feed: how does it affect their performance and health? BMC Veterinary Research, 15, 67. doi:10.1186/s12917-019-1808-x.

6. Došen R., Prodanov-Radulović J., Pušić I., Ratajac R., Stojanov I., Grubač S. 2014. The uncontrolled use of antibiotics in pig production - a threat to public health. In Proceedings, XVI International congress Feed technology, edited by Bojana Kokić, Novi Sad, Institute of food technology, 20-24. ISBN 978-86-7994-044-5.

7. Echtermann T., Muentener C., Sidler X., Kümmerlen D. 2019. Antimicrobial Drug Consumption on Swiss Pig Farms: A Comparison of Swiss and European Defined Daily and Course Doses in the Field. Frontiers in Veterinary Science, 6, 240. doi:10.3389/fvets.2019.00240.

8. Laanen M., Persoons D., Ribbens S., de Jong E., Callens B., Strubbe M., Maes D., Dewulf J. 2013. Relationship between biosecurity and production/antimicrobial treatment characteristics in pig herds. The Veterinary Journal, 198, 2, 508-512. doi:10.1016/j.tvjl.2013.08.029.

9. McEwen S.A. and Fedorka-Cray P.J. 2002. Antimicrobial Use and Resistance in Animals. Clinical Infectious Diseases, 34, 3, 93-106. doi:10.1086/340246.

10. Postma M., Backhans A., Collineau L., Loesken S., Sjölund M., Belloc C., Emanuelson U., Beilage E., Nielsen E.O., Stärk K.D.C., Dewulf J., MINAPIG consortium. 2016. Evaluation of the relationship between the biosecurity status, production parameters, herd characteristics and antimicrobial usage in farrow-to-finish pig production in four EU countries. Porcine Health Management, 2, 9. doi:10.1186/s40813-016-0028-z.

11. Prodanov-Radulović J., Došen R., Stojanov I., Polaček V., Milanov D., Pušić I., Grubač S. 2014a. Neonatal diarrhea in pigs caused by Clostridium perfringens. Arhiv veterinarske medicine, 7, 1, 49-58. doi:10.46784/e-avm. v7i1.124.

12. Prodanov-Radulović J., Došen R., Stojanov I., Polaček V., Milanov D., Pušić I., Marčić D. 2014b. Swine dysentery: Practical observations, control and diagnostics. Proceedings of the International Symposium on Animal Science, Belgrade, Serbia, Faculty of Agriculture, editor in chief Zoran Popović, Beograd, Faculty of Agriculture, 379-385. ISBN 978-86-7834-199-1. 
13. Prodanov-Radulović J., Došen R., Stojanov I., Polaček V., Živkov-Baloš M., Marčić D. 2015a. Gastroenteritis caused by Escherichia coli in suckling pigs: clinical, pathological and microbiological findings. In Proceedings of the International Symposium on Animal Science (ISAS), 19th International Congress on Biotechnology in Animal Reproduction, edited by Snežana Trivunović, Novi Sad, Faculty of Agriculture, 212-217. ISBN 97886-7520-348-3.

14. Prodanov-Radulović J., Došen R., Pušić I., Petrović T., Apić J., Stojanov I., Polaček V. 2015b. Emergence of pseudorabies virus (Morbus Aujeszky) infection at large swine farms in AP Vojvodina (Serbia). Contemporary Agriculture, 64, 1-2, 105-111.

15. Prodanov-Radulović J, Živkov-Baloš M, Jakšić S, Grgić Ž, Stojanov I, Bojkovski J, Tassis P.D. 2017a. Aflatoxin M1 levels in sow milk. Journal of the Hellenic Veterinary Medical Society, 68, 3, 341-346. doi:10.12681/ jhvms.15487.

16. Prodanov-Radulović J., Petrović T., Lupulović D., Marčić D., Petrović J., Grgić Ž., Lazić S. 2017b. First detection and clinical presentation of Porcine epidemic diarrhea virus (PEDV) in Serbia. Acta Veterinaria-Beograd, 67, 3, 383-396. doi:10.1515/acve-2017-0031.

17. Prodanov-Radulović J., Pušić I., Živkov-Baloš M., Božić B., Polaček V., Grubač S., Bojkovski J. 2018. Kontrola mera biosigurnosti u svinjarskoj proizvodnji. Ecologica, 25, 91, 604-607.

18. Prodanov-Radulović J., Vučićević I., Polaček V., Aleksić-Kovačević. 2020. Current swine respiratory diseases morphology in intensive swine production in Serbia. Acta Veterinaria-Beograd 70, 1, 1-36. doi:10.2478/acve2020-0001.

19. Raasch S., Postma M., Dewulf J., Stärk K.D.C., Beilage E. 2018. Association between antimicrobial usage, biosecurity measures as well as farm performance in German farrow-to-finish farms. Porcine Health Management, 4, 30. doi:10.1186/s40813-018-0106-5.

20. Raasch S., Collineau L., Postma M., Backhans A, Sjölund M, Belloc C., Emanuelson U, Beilage E., Stärk K, Dewulf J., MINAPIG Consortium. 2020. Effectiveness of alternative measures to reduce antimicrobial usage in pig production in four European countries. Porcine Health Management, 6, 6. doi:10.1186/s40813-020-0145-6.

21. Savić B., Radanović O., Jovičić D., Nešić K., Ivanović S., Stevančević O., Cvetojević Đ., Kasagić D. 2015. Survey of infectious agents associated with porcine respiratory disease complex (PRDC) in Serbian swine herds using polymerase chain reaction (PCR) detection. Acta Veterinaria-Beograd, 65, 1, 79-88. doi:10.1515/acve-2015-0006. 
22. Silbergeld E.K., Graham J., Price L.B. 2008. Industrial food animal production, antimicrobial resistance, and human health. Annual review of public health, 29, 151-169. doi:10.1146/annurev.publhealth.29.020907.090904.

23. Sjölund M., Postma M., Collineau L., Lösken S., Backhans A., Belloc C., Emanuelson U., Beilage E., Stärk K., Dewulf J. and MINAPIG consortium. 2016. Quantitative and qualitative antimicrobial usage patterns in farrowto-finish pig herds in Belgium, France, Germany and Sweden. Preventive Veterinary Medicine, 130, 41-50. doi:10.1016/j.prevetmed.2016.06.003.

Submitted: 10.06 .2020 . Accepted: 02.08.2020. 